\title{
Penentuan Prioritas Perbaikan Kualitas Layanan TransJakarta dengan Menggunakan Metode IPA-PGCV
}

\author{
Ronald Sukwadi ${ }^{1 *}$, Jufina ${ }^{2}$ \\ 1*,2) Fakultas Teknik, Jurusan Teknik Industri, \\ Universitas Katolik Indonesia Atma Jaya \\ Jl. Jenderal Sudirman 51, Jakarta 12930. \\ email : ronald.sukwadi@atmajaya.ac.id, ronaldmanutd@yahoo.com
}

\begin{abstract}
TransJakarta was a Bus Rapid Transit (BRT) system in Jakarta. It was designed to provide Jakarta citizens with a fast public transportation system to help reduce rush hour traffic. After operating more than one decade, many suggestions and critics were given related to service quality. IPA and PGCV methods were applied to determine which service attributes should be improved and their priorities. In this research, eight service attributes were identified as critical attributes (on first quadrant of IPA diagram). The higher value of PGCV index indicated the priority level of attributes. Based on its priority level, the order were 1) easiness of giving suggestions, 2) ticket queue, 3) easiness of complaints, 4) the facilities for passengers with special needs, 5) employees appearance, 6) transportation cost, 7) accessibility, and 8) the number of bus.
\end{abstract}

Keywords: Service Quality, IPA, PGCV,Priority

\begin{abstract}
Abstrak
TransJakarta merupakan sistem transportasi bis di Jakarta. Sistem ini dirancang untuk warga Jakarta sebagai alat transportasi umum dalam rangka mengurangi kemacetan ibu kota. Setelah beroperasi kurang lebih satu dekade di Jakarta, banyak saran dan kritik berkaitan dengan kualitas layanan yang diberikan. Metode IPA dan PGCV digunakan untuk menentukan atribut yang harus diperbaiki dan prioritasnya. Dalam penelitian ini, terindentifikasi terdapat 8 atribut layanan atribut kritis (pada kuadran pertama diagram IPA ). Semakin besar nilai indeks PGCV maka akan menjadi prioritas perbaikan. Adapun urutan perbaikannya yaitu: 1) Kemudahan memberikan saran, 2) Waktu untuk mengantri tiket, 3) Kemudahan menyampaikan pengaduan, 4) Ketersediaan fasilitas bagi penumpang berkebutuhan khusus, 5) Penampilan pegawai TransJakarta, 6) Biaya TransJakarta, 7) Kemudahan menjangkau halte TransJakarta, dan 8) Jumlah armada bus Transjakarta.
\end{abstract}

Kata Kunci: Kualitas Layanan, IPA, PGCV, Prioritas

\section{Pendahuluan}

Seiring dengan meningkatnya kesibukan di ibu kota, kemacetan menjadi salah satu masalah besar yang dihadapi oleh masyarakat. Pemerintah menghadirkan adanya transportasi baru yang dapat menjadi solusi masalah tersebut. Solusi yang diberikan itu adalah dengan adanya TransJakarta. TransJakarta atau yang lebih umum

\footnotetext{
*Korespondensi Penulis
}

dikenal dengan busway merupakan salah satu transportasi yang sedang berkembang saat ini di Indonesia (Sukwadi dan Liu, 2014). Sejak 15 Januari 2004, pemerintah kota Jakarta mulai mengoperasikan koridor pertama yaitu koridor Blok M-Kota. Permintaan akan TransJakarta terus meningkat sampai dengan saat ini. Pada awal masa beroperasinya, jumlah penumpang pada tahun 2004 sebanyak 14 juta penumpang. Sampai dengan akhir tahun 2013, 
jumlah penumpang TransJakarta mencapai 3,6 miliar penumpang.

Sampai dengan saat ini, TransJakarta tetap menjadi salah satu transportasi pilihan masyarakat pada umumnya. Pemerintah daerah pun terus mengembangkan jalur ataupun koridor penggunaan TransJakarta. Selain itu, pemerintah daerah juga telah menambahkan armada bus baru untuk memenuhi kebutuhan masyarakat akan TransJakarta. Ini merupakan beberapa hal yang menjadi alasan bahwa TransJakarta menjadi salah satu transportasi pilihan masyarakat di Jakarta.

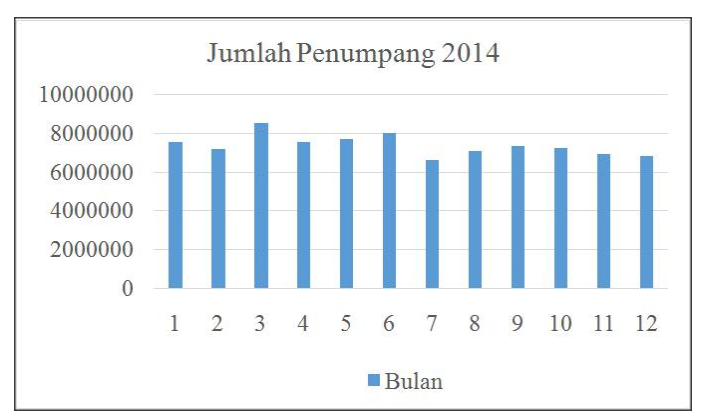

Gambar 1: Grafik Jumlah Penumpang TransJakarta Tahun 2014

(www.transjakarta.co.id)

Setelah beroperasi kurang lebih selama sepuluh tahun di Jakarta, penggunaan TransJakarta mendapatkan berbagai saran dan kritik atas keluhan pelanggan. Besarnya minat masyarakat dalam menggunakan TransJakarta sebagai transportasi umum, tidak menutup kemungkinan adanya daya saing jenis transportasi lain dalam menarik minat masyarakat. Hal ini juga dikarenakan bahwa TransJakarta belum beroperasi dengan maksimal. Hal ini berkaitan erat dengan kualitas yang diberikan oleh pihak penyedia TransJakarta tersebut. Walaupun TransJakarta telah cukup banyak menarik minat masyarakat, kehadiran TransJakarta juga banyak mendapat keluhan dari masyarakat. Kualitas pelayanan yang diberikan oleh penyedia TransJakarta menyebabkan tidak jarang adanya masyarakat yang berpindah kepada jenis transportasi lainnya. Persaingan pihak TransJakarta dalam meningkatkan kualitas ini diperlukan adanya usaha untuk memenuhi hal-hal yang menjadi harapan masyarakat sehingga masyarakat memperoleh kepuasan atas pelayanan yang diberikan oleh pemerintah (Sukwadi dan Liu, 2014).

Untuk mendapatkan kepuasan masyarakat, maka pemerintah perlu terus meningkatkan pelayanan yang diberikan. Hal ini dikarenakan masyarakat saat ini semakin kritis mem- berikan penilaian terhadap kualitas pelayanan transpotasi yang tersedia. Ini dipengaruhi oleh tingkat pendidikan yang meningkat, kemampuan ekonomi masyarakat dan tak lepas juga dari pengaruh media massa. Dengan demikian, perlu adanya analisis mengenai kepentingan atau harapan masyarakat terhadap faktor-faktor yang mempengaruhi penilaian pelayanan TransJakarta dan bagaimana kinerja pihak TransJakarta dalam memenuhi harapan masyarakat sehingga masyarakat memperoleh kepuasan. Hal ini akan mempertahankan TransJakarta dalam kondisi bersaing, bahkan akan meningkatkan kondisi persaingan. Herbowo (2012) menyatakan bahwa menyatakan bahwa pengguna menginginkan ditingkatkannya jumlah armada. Selain itu, tingkat kriminalitas dirasakan juga masih tinggi oleh pengguna. Menurut Hutapea et al. (2011) menyatakan bahwa ketepatan waktu bus merupakan salah satu faktor yang mengukur efisiensi kerja bus TransJakarta. Dengan demikian, maka pemerintah harus memberikan perhatian lebih yang memang dianggap penting oleh masyarakat.

Berdasarkan uraian di atas, maka penulis berminat untuk melakukan penelitian mengenai analisis kualitas pelayanan transportasi TransJakarta. Dengan menganalisis tingkat kepentingan atau harapan (importance) masyarakat dan kinerja (performance) pihak TransJakarta TransJakarta, maka dapat diketahui sejauh mana tingkat perbaikan yang diinginkan oleh masyarakat terhadap pelayanan yang mereka peroleh. Dalam hal ini, metode Importance Performance Analysis (IPA) yang dikenalkan oleh (Martilla dan James, 1977) digunakan dalam penelitian ini. Isfarani et al. (2011) menjelaskan bahwa metode IPA ini memiliki kelebihan dibandingkan dengan metode yang lain adalah sebagai berikut:

1. Prosedur dari metode yang digunakan cukup sederhana

2. Pengambil kebijakan dapat dengan mudah menentukan prioritas kegiatan yang harus dilakukan dengan sumber daya yang terbatas

3. Metode IPA cukup fleksibel untuk diterapkan pada berbagai bidang

Nilai pelanggan (customer value) merupakan preferensi yang dirasakan oleh pelanggan berdasarkan hasil evaluasi pelanggan tersebut terhadap atribut produk atau jasa (Woodruff, 1997; Sukwadi et al., 2012). Selanjutnya melalui metode Potential Gain in Customer Value (PGCV) (Parasuraman, 1997; Woodruff, 1997) diharapkan akan memberikan hasil berkaitan dengan 
atribut apa yang secara prioritas harus diperbaiki untuk memenuhi kepuasan penumpang. Metode PGCV pernah digunakan dalam penelitian di salah satu cabang bank di Medan (Siregar, 2006). Beliau berpendapat bahwa analisis pelanggan melalui indeks PGCV merupakan konsep yang mudah untuk menganalisis pelanggan.

Menurut Darmawan et al. (2014), PGCV merupakan pelengkap dari metode IPA. Metode ini merupakan metode yang mudah dilakukan untuk menganalisis pelanggan. Kemudahan tersebut memberikan jalan bagi diagram kartesius IPA untuk dibandingkan dalam bentuk kualitatif yang lebih terperinci. Metode PGCV ini dapat menganalisis masing-masing atribut yang diteliti. Kelebihan inilah yang dapat digunakan untuk melengkapi analisis IPA di mana metode tersebut hanya membagi atribut ke dalam bagian yang perlu prioritas perbaikan atau tidak. Hasil penelitian ini diharapkan dapat menjadi masukan dan evaluasi bagi TransJakarta untuk membantu dalam menentukan strategi-strategi yang berorientasi pada peningkatan kualitas pelayanan dan kepuasan masyarakat. Tujuan dari penelitian ini adalah:

1. Melakukan analisis untuk melihat kesesuaian antara tingkat kepentingan (Importance) dan kepuasan atau kinerja (Satisfaction or Performance) masyarakat terhadap kualitas pelayanan pihak transportasi TransJakarta.

2. Menentukan prioritas perbaikan layanan berdasarkan tingkat kesesuaian dan Potential Gain in Customer Value (PGCV) dalam meningkatkan kualitas pelayanan pihak transportasi TransJakarta.

\section{Metode Penelitian}

\subsection{Desain Penelitian}

Obyek dalam penelitian ini adalah TransJakarta. Responden yang dipilih memiliki kriteria rutin menggunakan TransJakarta sebagai sarana transportasi minimal 3 kali seminggu sehingga diharapkan dapat menilai kualitas layanan pihak TransJakarta. Data diperoleh melalui penyebaran kuesioner pada penumpang TransJakarta di semua koridor dengan teknik purposive sampling. Kuesioner terbagi menjadi dua bagian besar. Bagian pertama berisi pernyataan mengenai data demografi responden. Bagian kedua berisi 33 pernyataan yang berkaitan dengan kualitas layanan yang disediakan oleh pihak TransJakarta. Pada bagian ini, responden diminta memilih satu dari lima pilihan jawaban yang dituliskan dalam skala pengukuran Likert 1 sampai 5, masing-masing menunjukkan sangat tidak puas (1) sampai sangat puas (5) (untuk menilai tingkat kepuasan) serta sangat tidak penting (1) sampai sangat penting (5) (untuk menilai tingkat kepentingan) dari setiap pernyataan dalam kuesioner. Sebanyak 420 kuesioner disebarkan secara langsung di semua koridor, dan hasilnya sebanyak 400 kuesioner yang dapat dianalisis lebih lanjut. Penelitian yang dilakukan mengikuti alur metodologi penelitian pada Gambar 2.

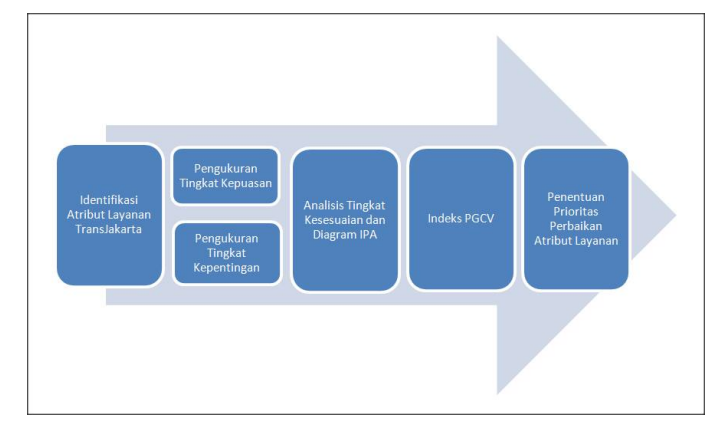

Gambar 2: Alur Metodologi Penelitian

\section{Hasil dan Pembahasan}

\subsection{Profil Responden}

Profil responden penumpang TransJakarta dapat dilihat pada Tabel 1.

Tabel 1: Profil responden $(\mathrm{N}=400)$

\begin{tabular}{|c|c|c|c|}
\hline \multicolumn{2}{|c|}{ Karakteristik } & \multicolumn{2}{c|}{ Jumlah } \\
\hline \multirow{4}{*}{ Jenis Kelamin } & Pria & 278 & $66 \%$ \\
\cline { 2 - 4 } & Wanita & 142 & $34 \%$ \\
\hline \multirow{4}{*}{ Umur } & $17-25$ tahun & 53 & $13 \%$ \\
\cline { 2 - 4 } & $26-35$ tahun & 205 & $49 \%$ \\
\cline { 2 - 4 } & $36-45$ tahun & 108 & $26 \%$ \\
\cline { 2 - 4 } & $46-55$ tahun & 54 & $13 \%$ \\
\hline \multirow{5}{*}{ Frekuensi } & $3-6$ kali seminggu & 126 & $30 \%$ \\
\cline { 2 - 4 } & $7-10$ kali seminggu & 221 & $53 \%$ \\
\cline { 2 - 4 } & Lebih dari 10 kali & 73 & $17 \%$ \\
\hline \multirow{5}{*}{ Waktu Penggunaan } & seminggu & & \\
\cline { 2 - 4 } & Pergi saja & 27 & $6 \%$ \\
\cline { 2 - 4 } & Pulang saja & 176 & $42 \%$ \\
\hline \multirow{5}{*}{ Pekerjaan } & Pulang Pergi & 217 & $52 \%$ \\
\cline { 2 - 4 } & Pelajar Mahasiswa & 57 & $14 \%$ \\
\cline { 2 - 4 } & Pegawai Negeri & 69 & $16 \%$ \\
\cline { 2 - 4 } & Pegawai Swasta & 184 & $44 \%$ \\
\cline { 2 - 4 } & Buruh & 43 & $100 \%$ \\
\cline { 2 - 4 } & Wiraswasta & 62 & $15 \%$ \\
\cline { 2 - 4 } & Lain-lain & 5 & $1 \%$ \\
\hline
\end{tabular}




\subsection{Tingkat Kesesuaian dan Diagram IPA}

Tingkat kesesuaian yang dapat dihitung dari hasil kinerja atribut tersebut dibandingkan dengan tingkat harapan atau kepentingan dari penumpang. Hasilnya dapat dilihat pada Tabel 2. Hasil pemetaan nilai kinerja atau kepuasan terhadap suatu atribut dan nilai kepentingannya dapat dilihat pada diagram IPA (Gambar 3).

Tabel 2: Hasil Tingkat Kesesuaian

\begin{tabular}{|c|c|c|c|c|}
\hline No & Atribut & $\begin{array}{l}\text { Tingkat } \\
\text { Kinerja }\end{array}$ & $\begin{array}{l}\text { Tingkat } \\
\text { Kepentin- } \\
\text { gan }\end{array}$ & $\begin{array}{c}\text { Tingkat } \\
\text { Kesesua- } \\
\text { ian }\end{array}$ \\
\hline 1 & $\begin{array}{l}\text { Lantai, jendela, dinding, pintu dan } \\
\text { atap halte TransJakarta dalam keadaan } \\
\text { baik dan bersih }\end{array}$ & 1004 & 1787 & $56 \%$ \\
\hline 2 & $\begin{array}{l}\text { Suhu di dalam halte TransJakarta } \\
\text { cukup baik }\end{array}$ & 992 & 1799 & $55 \%$ \\
\hline 3 & $\begin{array}{l}\text { Penerangan di dalam halte } \\
\text { TransJakarta cukup baik }\end{array}$ & 908 & 1797 & $51 \%$ \\
\hline 4 & Halte bus TransJakarta cukup banyak & 1020 & 1808 & $56 \%$ \\
\hline 5 & Halte TransJakarta mudah dijangkau & 980 & 1897 & $52 \%$ \\
\hline 6 & $\begin{array}{l}\text { Ketersediaan hotspot, minuman ringan } \\
\text { dan toilet, papan petunjuk koridor dan } \\
\text { rute bus TransJakarta }\end{array}$ & 1007 & 1806 & $56 \%$ \\
\hline 7 & $\begin{array}{l}\text { Interior Bus TransJakarta bebas dari } \\
\text { sampah }\end{array}$ & 913 & 1772 & $52 \%$ \\
\hline 8 & $\begin{array}{l}\text { Eksterior Bus TransJakarta bebas dari } \\
\text { kotoran debu }\end{array}$ & 1003 & 1754 & $57 \%$ \\
\hline 9 & $\begin{array}{l}\text { Suhu di dalam bus TransJakarta cukup } \\
\text { baik }\end{array}$ & 975 & 1748 & $56 \%$ \\
\hline 10 & $\begin{array}{l}\text { Penerangan di dalam bus TransJakarta } \\
\text { cukup baik }\end{array}$ & 948 & 1768 & $54 \%$ \\
\hline 11 & $\begin{array}{l}\text { Penumpang dalam bus TransJakarta } \\
\text { sesuai dengan kapasitas maksimum }\end{array}$ & 927 & 1774 & $52 \%$ \\
\hline 12 & $\begin{array}{c}\text { Ketersedian fasilitas bus TransJakarta } \\
\text { bagi penumpangan dengan kebutuhan } \\
\text { khusus }\end{array}$ & 927 & 1821 & $51 \%$ \\
\hline 13 & $\begin{array}{c}\text { Armada bus TransJakarta cukup } \\
\text { banyak }\end{array}$ & 960 & 1846 & $52 \%$ \\
\hline 14 & $\begin{array}{l}\text { Pegawai TransJakarta berpenampilan } \\
\text { rapi dan bersih }\end{array}$ & 977 & 1899 & $51 \%$ \\
\hline 15 & Biaya TransJakarta terjangkau & 988 & 1918 & $52 \%$ \\
\hline 16 & Ketepatan jadwal bus Transjakarta & 1225 & 1803 & $68 \%$ \\
\hline 17 & $\begin{array}{c}\text { Kebutuhan waktu yang dibutuhkan } \\
\text { untuk menurunkan dan menaikan } \\
\text { penumpang }\end{array}$ & 1287 & 1795 & $72 \%$ \\
\hline 18 & $\begin{array}{l}\text { Kecukupan jarak pintu halte dan pintu } \\
\text { bus TransJakarta }\end{array}$ & 1475 & 1843 & $80 \%$ \\
\hline 19 & $\begin{array}{l}\text { Jangkauan rute TransJakarta yang luas } \\
\text { dan penting }\end{array}$ & 1485 & 1871 & $79 \%$ \\
\hline 20 & $\begin{array}{l}\text { Kemudahan sistem pembayaran dan } \\
\text { pembelian tiket }\end{array}$ & 1504 & 1848 & $81 \%$ \\
\hline 21 & $\begin{array}{c}\text { Kejelasan pembagian wilayah dalam } \\
\text { bus TransJakarta untuk penumpang } \\
\text { berbeda gender }\end{array}$ & 1581 & 1817 & $87 \%$ \\
\hline 22 & $\begin{array}{c}\text { Penumpang dapat dengan mudah } \\
\text { mendapatkan informasi }\end{array}$ & 1381 & 1679 & $82 \%$ \\
\hline 23 & $\begin{array}{l}\text { Penumpang tidak perlu mengantri } \\
\text { tiket dengan waktu yang lama }\end{array}$ & 883 & 1843 & $48 \%$ \\
\hline 24 & $\begin{array}{l}\text { Penumpang dapat dengan mudah } \\
\text { menyampaikan pengaduan }\end{array}$ & 913 & 1888 & $48 \%$ \\
\hline 25 & $\begin{array}{l}\text { Penumpang dapat dengan mudah } \\
\text { memberikan saran }\end{array}$ & 854 & 1881 & $45 \%$ \\
\hline 26 & $\begin{array}{l}\text { Keamanan dalam halte Transjakarta } \\
\text { terjamin }\end{array}$ & 1349 & 1882 & $72 \%$ \\
\hline 27 & $\begin{array}{c}\text { Keamanan dalam bus TransJakarta } \\
\text { terjamin }\end{array}$ & 1370 & 1813 & $76 \%$ \\
\hline 28 & $\begin{array}{c}\text { Keselamatan penumpang selama } \\
\text { perjalanan dan mengantri TransJakarta } \\
\text { terjamin }\end{array}$ & 1296 & 1797 & $72 \%$ \\
\hline 29 & $\begin{array}{c}\text { Jalur bus TransJakarta terjamin aman } \\
\text { dan steril dari kendaraan lain }\end{array}$ & 965 & 1808 & $53 \%$ \\
\hline 30 & $\begin{array}{c}\text { Petugas kasir ramah dan } \\
\text { memperhatikan penumpang }\end{array}$ & 1431 & 1836 & $78 \%$ \\
\hline 31 & $\begin{array}{l}\text { Kondektur ramah dan memperhatikan } \\
\text { penumpang }\end{array}$ & 1398 & 1822 & $77 \%$ \\
\hline 32 & $\begin{array}{l}\text { Supir mengemudi dengan hati-hati } \\
\text { dan sabar }\end{array}$ & 1340 & 1905 & $70 \%$ \\
\hline 33 & $\begin{array}{l}\text { Layanan pengaduan memperhatikan } \\
\text { dan memahami penumpang }\end{array}$ & 1328 & 1753 & $76 \%$ \\
\hline \multicolumn{4}{|c|}{ Rata-rata } & $63 \%$ \\
\hline
\end{tabular}

Pada Gambar 3 dapat dilihat bahwa atributatribut terbagi ke dalam empat kuadran. Kuad- ran pertama yang menjadi prioritas utama terdiri atas butir atribut nomor 5, 12, 13, 14, 15, 23, 24, dan 25. Ini berarti atribut tersebut menjadi prioritas perbaikan oleh pihak TranJakarta dengan segera. Kuadran kedua yang menjadi prestasi yang harus dipertahankan yaitu atribut nomor 18, 19, 20, 26, 30, 31 dan 32. Atribut ini menunjukan bahwa TransJakarta telah memberikan pelayanan sesuai dengan harapan konsumen. Kuadran ketiga yang menjadi prioritas rendah yaitu atribut nomor $1,2,3,4,6,7,8,9,10$, 11, dan 29. Atribut pada kuadran ini menunjukan bahwa pihak TransJakarta dapat melakukan perbaikan untuk meningkatkan kualitas pelayanan TransJakarta. Kuadran keempat terdiri atas atribut nomor 16, $17,21,22,27,28$, dan 33. Atribut pelayanan yang diberikan oleh pihak TransJakarta pada kuadran ini melebihi harapan dari konsumen.

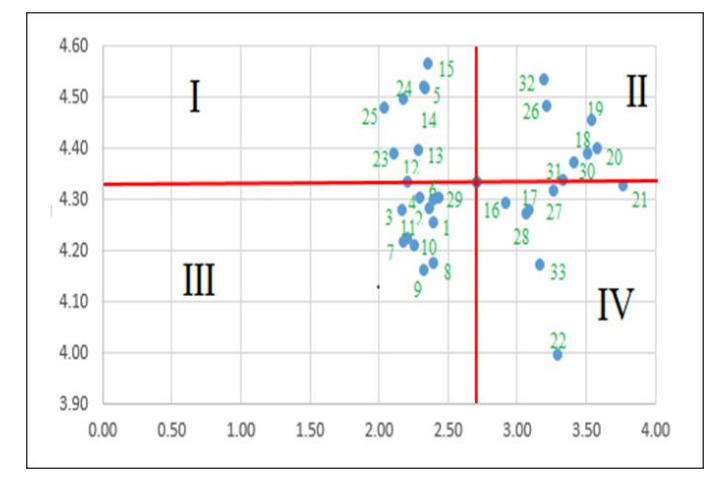

Gambar 3: Diagram Kartesius IPA

\subsection{Penentuan Indeks PGCV}

Nilai Achieve Customer Value (ACV) menunjukan besarnya nilai kualitas pelayanan yang tercapai menurut sudut pandang penumpang. Jika nilai ACV semakin besar maka ini berarti bahwa kualitas pelayanan pihak TransJakarta semakin baik dari sudut pandang penumpang, berlaku hal sebaliknya. Sedangkan, nilai UDCV merupakan nilai akhir yang diinginkan penumpang. Indeks PGCV menunjukan selisih dari nilai yang diharapkan oleh penumpang dengan nilai yang diperoleh penumpang. Hal ini berarti bahwa semakin besar nilai indeks PGCV maka penumpang merasa kurang puas sehingga atribut tersebut harus dilakukan perbaikan. Nilai indeks ini digunakan untuk menentukan atribut-atribut mana saja yang berpotensi paling besar dalam memberikan nilai tambah kualitas atau keuntungan. Tabel 3 menyajikan hasil perhitungan indeks PGCV. 
Tabel 3: Perhitungan Indeks PGCV

\begin{tabular}{|c|c|c|c|}
\hline No Atribut & Nilai ACV & Nilai UDCV & Indeks PGCV \\
\hline 1 & 10.17 & 21.27 & 11.10 \\
\hline 2 & 10.12 & 21.42 & 11.30 \\
\hline 3 & 9.25 & 21.39 & 12.14 \\
\hline 4 & 10.45 & 21.52 & 11.07 \\
\hline 5 & 10.54 & 22.58 & 12.04 \\
\hline 6 & 10.31 & 21.50 & 11.19 \\
\hline 7 & 9.17 & 21.10 & 11.92 \\
\hline 8 & 9.97 & 20.88 & 10.91 \\
\hline 9 & 9.66 & 20.81 & 11.15 \\
\hline 10 & 9.50 & 21.05 & 11.55 \\
\hline 11 & 9.32 & 21.12 & 11.80 \\
\hline 12 & 9.57 & 21.68 & 12.11 \\
\hline 13 & 10.05 & 21.98 & 11.93 \\
\hline 14 & 10.52 & 22.61 & 12.09 \\
\hline 15 & 10.74 & 22.83 & 12.09 \\
\hline 16 & 12.52 & 21.46 & 8.94 \\
\hline 17 & 13.10 & 21.37 & 8.27 \\
\hline 18 & 15.41 & 21.94 & 6.53 \\
\hline 19 & 15.75 & 22.27 & 6.52 \\
\hline 20 & 15.76 & 22.00 & 6.24 \\
\hline 21 & 16.29 & 21.63 & 5.35 \\
\hline 22 & 13.14 & 19.99 & 6.84 \\
\hline 23 & 9.23 & 21.94 & 12.72 \\
\hline 24 & 9.77 & 22.48 & 12.70 \\
\hline 25 & 9.11 & 22.39 & 13.29 \\
\hline 26 & 14.39 & 22.40 & 8.01 \\
\hline 27 & 14.08 & 21.58 & 7.50 \\
\hline 28 & 13.20 & 21.39 & 8.19 \\
\hline 29 & 9.89 & 21.52 & 11.63 \\
\hline 30 & 14.89 & 21.86 & 6.96 \\
\hline 31 & 14.44 & 21.69 & 7.25 \\
\hline 32 & 14.47 & 22.68 & 8.21 \\
\hline 33 & 13.20 & 20.87 & 7.67 \\
\hline
\end{tabular}

\subsection{Penentuan Prioritas Perbaikan Atribut Layanan}

Sesuai dengan konsep diagram IPA, fokus perbaikan dilakukan terhadap pihak TransJakarta yaitu pada atribut-atribut yang berada dalam kuadran pertama. Adapun penentuan prioritas berdasarkan tingkat keesuaian dan nilai indeks PGCV. Atribut dengan prioritas perbaikan pertama apabila memiliki tingkat keseuaian terendah dan nilai indeks PGCV tertinggi.

Tabel 4: Urutan Prioritas Perbaikan Berdasarkan Hasil IPA dan PGCV

\begin{tabular}{|c|c|c|c|c|}
\hline $\begin{array}{c}\text { No } \\
\text { Atribut }\end{array}$ & Atribut Layanan & $\begin{array}{c}\text { Tingkat } \\
\text { Kesesua- } \\
\text { ian }\end{array}$ & $\begin{array}{c}\text { Indeks } \\
\text { PGCV }\end{array}$ & $\begin{array}{c}\text { Urutan } \\
\text { Prioritas }\end{array}$ \\
\hline 5 & $\begin{array}{c}\text { Kemudahan menjangkau halte bus } \\
\text { TransJakarta }\end{array}$ & $52 \%$ & 12.04 & 7 \\
\hline 12 & $\begin{array}{c}\text { Ketersedian fasilitas bus } \\
\text { TransJakarta bagi penumpang } \\
\text { dengan kebutuhan khusus }\end{array}$ & $51 \%$ & 12.11 & 4 \\
\hline 13 & Jumlah armada bus TransJakarta & $52 \%$ & 11.93 & 8 \\
\hline 14 & Penampilan pegawai TransJakarta & $51 \%$ & 12.09 & 5 \\
\hline 15 & Biaya TransJakarta & $52 \%$ & 12.09 & 6 \\
\hline 23 & $\begin{array}{c}\text { Waktu untuk mengantri tiket bus } \\
\text { TransJakarta }\end{array}$ & $48 \%$ & 12.72 & 2 \\
\hline 24 & $\begin{array}{c}\text { Kemudahan penumpang dalam } \\
\text { menyampaikan pengaduan }\end{array}$ & $48 \%$ & 12.7 & 3 \\
\hline 25 & $\begin{array}{c}\text { Kemudahan dalam memberikan } \\
\text { saran }\end{array}$ & $45 \%$ & 13.29 & 1 \\
\hline
\end{tabular}

Tabel 4 menyajikan urutan prioritas atribut pada kuadran pertama IPA dan perhitungan indeks PGCV-nya

\section{Kesimpulan}

Berdasarkan hasil penelitian mengenai kualitas pelayanan TransJakarta, maka dapat disimpulkan sebagai berikut :

1. Tingkat Kesesuaian memberikan hasil perhitungan bahwa terdapat 19 atribut kualitas pelayanan Transjakarta yang memerlukan perbaikan dan 14 atribut lainnya dapat dipertahankan.

2. Pemetaan dengan diagram Importance Performance Analysis (IPA) menempatkan 8 atribut ke dalam kuadran prioritas utama, 7 atribut di kuadran pertahankan pelayanan, 11 atribut di kuadran prioritas rendah dan 7 atribut dalam kuadran berlebihan.

3. Atribut-atribut yang berada dalam kuadran prioritas utama dalam perhitungan IPA yaitu ; kemudahan menjangkau halte bus TransJakarta, ketersediaan fasilitas bus TransJakarta bagi penumpang dengan kebutuhan khusus, jumlah armada bus TransJakarta, penampilan pegawai TransJakarta, biaya TransJakarta, waktu untuk mengantri tiket bus TransJakarta, kemudahan penumpang dalam menyampaikan pengaduan, dan kemudahan penumpang dalam memberikan saran.

4. Atribut pada kuadran pertama dan ketiga memiliki tingkat kesesuaian di bawah tolak ukur yaitu sebesar 63\% sehingga keputusan seluruh atributnya yaitu adanya perbaikan.

5. Metode Importance Performance Analysis (IPA) dan Potential Gain in Customer Value (PGCV) memberikan urutan prioritas perbaikan pada kuadran prioritas utama dalam diagram kartesius dengan urutan sebagai berikut :

(a) Kemudahan penumpang dalam memberikan saran

(b) Waktu untuk mengantri tiket

(c) Kemudahan penumpang dalam menyampaikan pengaduan

(d) Ketersedian fasilitas bus TransJakarta bagi penumpangan dengan kebutuhan khusus

(e) Penampilan pegawai TransJakarta

(f) Biaya TransJakarta

(g) Kemudahan menjangkau halte TransJakarta

(h) Jumlah armada bus TransJakarta 


\section{Daftar Pustaka}

Darmawan, A., Mulyadi, \& Busri, N.K. (2014). Analisis Kepuasan Pelanggan Terhadap Layanan Purna Jual Avanza dengan Metode SERVQUAL dan PGCV. Jurnal Teknik Industri Universitas Hassanudin, Vol. 2(2), 12-19.

Herbowo, N. (2012). Studi Persepsi Pengguna TransJakarta Pada Koridor II (PulogadungHarmoni). Jurnal Perencanaan Wilayah dan Kota, Vol. 23(1), 37-50.

Hutapea, S. H., Michael \& Manik, I.N. (2011). Perancangan Program Simulasi Penjadwalan Busway-TransJakarta dengan Metode Repetitive Scheduling. Jurnal Sains dan Teknologi, Universitas Bina Nusantara, Jakarta. Vol. 11(1), 1-9.

Isfarani, Sulistio, H., \& Wicaksono, A. (2011). Kajian Karakteristik Angkutan Ojek Sepeda Motor dan Cidomo di Kota Mataram. Jurnal Rekayasa Sipil. Vol. 5(2), 84-94.

Martilla, J., \& James, J. (1977). ImportancePerformance Analysis. Journal of Marketing, Vol. 41(1),77-79.

Parasuraman, A. (1997). Reflections on Gaining Competitive Advantage through Customer Value. Journal of the Academy of Marketing Science, Vol. 25(2), 154-161

Siregar, S.F. (2006). Analisis Tingkat Kualitas Pelayanan Dengan Metode Index Potential Gain Customer Value (PGCV) di PT Bank Muamalat Indonesia Cabang Medan. Jurnal Sistem Teknik Industri. Vol. 7(4), 40-47.

Sukwadi, R., Yang, C.C., \& Fan, L. (2012). Capturing Customer Value Creation based on Service Experience - A Case Study on News Caf, Journal of the Chinese Institute of Industrial Engineers, Vol. 29(6), 383-399.

Sukwadi, R., \& Liu, F. (2014). The Use of Simulation Approaches in Improving the Performance of Jakarta BRT System, Proceeding of The 2nd International Conference on Intelligent Information System and Technology (ICIIST 2014), Qingdao, China, June $26-28$.

Woodruff, R. B. (1997). Customer Value: The Next Source of Competitive Advantage.Journal of the Academy of Marketing Science. Vol. 25(2), 139153 